\title{
How the social economy produces innovation
}

\author{
Jason Potts \\ School of Economics, Finance \& Marketing, RMIT University, Australia. \\ jason.potts@rmit.edu.au \\ John Hartley \\ Centre for Culture \& Technology, Curtin University, Australia. \\ School of Journalism, Media \& Cultural Studies, Cardiff University, Wales.
}

\begin{abstract}
Social economics has long been concerned with the effects on human societies of market-coordinated processes of economic innovation. But the social economy also causes invention and innovation, an aspect that has received less attention. This paper reviews three new approaches to the study of the growth of knowledge in economic systems as driven expressly by socio-cultural mechanisms and dynamics. The first are so-called 'social network markets' and 'novelty bundling markets'. The second extends from 'knowledge commons' to 'innovation commons'. The third is a socio-cultural semiotic process of group dynamics. These models represent different ways the social economy generates newness and produces innovation.
\end{abstract}

Keywords: innovation, social economics, cultural markets, knowledge commons, demes JEL: O31, O35, Z13, B52 


\section{INTRODUCTION}

'Mere accumulation is not enough. Economic development does not consist merely in the piling up of things, but in the accumulation of new kinds of things.'

- Kenneth Boulding (1964)

There are only a few overarching consensus positions in economics, but the nature and causes of economic growth is one of them. Neoclassical growth economists (Solow 1958), endogenous growth theorists (Romer 1986, Aghion and Howitt 1992), and evolutionary, Institutional and Austrian economists alike (Nelson and Winter 1982, Loasby 1999, Dopfer and Potts 2008) all converge on the proposition that longrun economic growth is largely explained as a growth of knowledge process in a market-capitalist economic system. The specific forms of economic institutions can seemingly exhibit considerable variation without significantly affecting this basic proposition (Hall and Soskice, 2001, Rodrik 2007), and so too can a wide variety of socio-cultural systems be accommodated within these institutions (North 2005, Greif 2006). The overarching point is that within a broad institutional range in which markets can openly function, enterprise is relatively free, capital investment is sufficiently secure, and governments adequately furnish public goods (including social order and external defense), then the main driver of long-run economic growth, and therefore determinant of progress in aggregate social welfare, is the arrival rate of new ideas in the form of technological change, as invention, and as innovation, the process by which it endogenously transforms the economy (Schumpeter 1934).

Now along the way social economics has inserted itself into this story at many points, particularly about the accommodation of economic institutions to the needs of human society, and about the redistribution of the gains from economic growth, and more broadly about the ethical meaning and human value of economic development (Etzioni 1988). But the one part of this account that has been systematically ignored by social economics is the very engine of this evolutionary dynamic process - namely the social economy as an explanation of the origins of novelty per se (Elam 1993). For the most part, the social economy is formulated as a response to novelty, innovation and technological growth (e.g. Boulding 1978), rather than as an explanation (e.g. Boulding 1956). The purpose of this paper, therefore, is to review 
the economics of the origin of new ideas, technology and innovation in order to propose some new models in which socio-cultural and semiotic processes (rather than resource allocation and organization, viz. Arrow 1962a, Lundvall 1992) are the main drivers of invention and innovation.

There is a very obvious sense in which innovation is product and process of the social economy. If we start with the social economy 'defined broadly as the complex intersection of markets, governments and communities' (Emami 2012: 401) then it is trivial to observe that innovation derives from markets (through innovating firms, patents), governments (publically funded $R \& D$, public science), and communities (social innovation (Mulgan 2013), user innovation (von Hippel 1988)). The innovation systems model shows how various kinds of activities, investments and actors and the interactions between different organizations and institutions are involved in technological advance (Nelson 1993, Freeman 1995, Sharif 2006). We can also appreciate how innovation and the development of new knowledge is shaped by the social economy, through its level of permissions, supports and restraints, and also how it is guided by its feedback, through the collective focus of science and technology resources onto certain social problems (Nelson 2011). Schumpeterian creative destruction is quite obviously a process that plays out socially and culturally, as well as technologically and industrially. But observe that these socio-cultural considerations are all in the manner of analysis of institutional forms that govern the processes that direct resources and shape the organization of innovation. None of this offers a theory of how sociocultural processes actually produce innovation. That remains something that research scientists, engineers, designers and entrepreneurs do. The social economy in this sense governs innovation, but seemingly it does not actually produce innovation.

It is of course possible to construct models of innovation that are assembled in terms of socio-cultural orderings and processes. The problem is that such approaches tend to fall outside the legitimate domain of economic analysis. Either they depart from models of rational choice subject to constraints (for example, innovation as 'creativity', or innovation emergent from particular characteristics of groups, such as $18^{\text {th }}$ century Protestants), or they depart from models of innovation constructed in terms of the allocation or organization of scarce resources. The three approaches we outline here all fall within what might at first seem to be the narrow ambit of a choice- 
theoretic economic analysis, however they are fundamentally descriptive of cultural processes that are elements of the social economy. We propose these three models as an analytic starting point for the development of a distinct social economics of the endogenous process of invention and innovation.

It is also clear that this domain of the socio-cultural effect on the development of new ideas has a long and serious history in the philosophy of science following the work of Thomas Kuhn, particular in the work by Paul Feyerabend (1975) on anarchist epistemology, which was a way of understanding the depth to which socio-cultural cultural processes were integrated into the scientific approach. In science and technology studies (Bijker et al. 1987) and related fields that draw on the sociology of science (MacKenzie and Wajcman 1985) a solid body of work has developed that illustrates the social construction of not only science but also of new technologies (Williams and Edge 1996). While running parallel to this, we certainly draw upon these ideas.

Our purpose here is to bring human values and social context into the study of the economics of innovation. The problem with the market failure model of innovation (Arrow 1962a) is precisely that it invites a raft of government solutions from intellectual property and corporate subsidy through to public research universities and government-run science laboratories (Martin and Scott 2000) - that tend to crowd-out civil society and community-level solutions. A social economics of innovation will seek to better understand the role that the social sector (cf. the market sector or the government sector) plays in the innovation process.

The three models illustrate the basic theme that we suggest is central to a social economics of innovation: namely the socio-cultural processing of uncertainty through harnessing the distributed knowledge of others. (Elam (1993) also emphasizes this point in relation to Ken Arrow's information economics.) 'Social network markets' and 'novelty bundling markets' both use socially distributed information to deal with innovation abundance. 'Innovation commons' enable the pooling of distributed information about a new technology through socio-culturally mediated groups. The theory of 'demic concentration' shows how knowledge-using culturally formed groups (demes) discover knowledge in the conflict of interactions with other demes. Social economics has contributed much to the study of the 
consequences of economic innovation, but we conclude that it might also contribute to the study of its causes too.

\section{ORIGINS OF INNOVATION}

While not always seen in distinction, and certainly containing much overlap, there are nevertheless two broad approaches that can be discerned from the perspective of social economics to the study of the process of invention and innovation, and the growth of knowledge in economic systems. These are the discovery model, in which economic resources are used to create a new idea that didn't exist before, and the learning model, in which economic resources are used to acquire an idea that exists somewhere else. Both discovery and learning have the same result from the micro perspective - the individual agent acquires novelty. But they have different systemic properties that formulate a different economic problem.

The discovery model is the macro model for the organization of the pursuit of knowledge that does not already exist, but must be discovered. This requires investing scarce resources, and has an uncertain pay-off. The economics of science (Nelson 1959, Arrow 1962a) and the economics of corporate or public R\&D (Dosi 1988) fit squarely here, and whether formulated at the level of the firm, industry or nation they are all modelled with a production function for knowledge in which economic resources are inputs and new ideas are outputs. In the absence of uncertainty, efficiency conditions are defined when the marginal cost of research inputs (e.g. research labour, research capital) equals the marginal benefit of research outputs (Stigler 1961). The discovery model describes the endogenous economics of the process by which the aggregate production frontier shifts outward through time by ongoing investment in knowledge discovery (Popper 1972). This model is usually then augmented by a theory of effective demand to explain why particular directions of research and discovery are favoured over others, and how the various market or social-democratic mechanisms direct the targeting of resources toward particular lines of discovery (Sarewitz and Nelson 2008)

The learning model focuses on the diffusion of knowledge rather than its origination. Specifically, it is concerned with the process by which knowledge is acquired that is new to the agent, firm, industry or nation, but that already exists 
elsewhere. This social process of evolutionary learning (Dosi et al 2005, Emami 2012) is used to understand firm-level competitive market processes driven by imitative learning and technology diffusion (Nelson and Winter 1982), industrial dynamics shaped by economic evolution; and catch-up and convergence in economic development (Romer 1986, Aghion and Howitt 1992). A variation on the learning model (temporal rather than spatial) is the self-learning model in which a technology runs down an average cost curve as a function of cumulative experience, also known as 'learning by doing' (Arrow 1962b).

Social learning is a powerful process that harnesses one of the main mechanisms in economic growth, namely what Adam Smith first diagnosed as the division of labour and specialization. What happens is that different people specialize in solving different problems and then we each of us copy the form of those specialized solutions by socially observing how specialized and skilled others act in particular situations. In the absence of social learning, agents have to discover (i.e. produce) all new information themselves, which is inefficient in opportunity cost terms. The very possibility of social progress and economic evolution thus depends upon an effective division of labour and division of knowledge in the production of new knowledge (Loasby 1999, Ziman 2000), which depends upon the communicative social systems of knowledge transmission required to re-coordinate all of this (McCloskey 2010, 2015). The social economy is a crucial aspect of this higher-order evolutionary economic process of knowledge discovery (specialization) and knowledge social learning (exchange). There are further overlaps between these models. For an individual, society or nation, investment in education is a process of social learning (vertical transmission) and investment in higher education will often extend to competitive processes of discovery. Firms may learn from observation of other firms (horizontal social learning) while at the same time engaged in $R \& D$ (competitive discovery). These will often be complementary investments, such that effort devoted to discovery increases the efficacy of social or imitative learning.

So there knowledge discovery there is social learning. These types of innovation processes are modeled as an allocation of resources to discovery (a production function approach) or to social learning (a gains from specialization approach). But there are three further types of innovation process that do not fit neatly into these standard templates of economic analysis. We organize these under three 
headings - (1) market adaptations; (2) knowledge commons; (3) and cultural demes but what these share is that they are cooperative, communicative and socio-cultural processes that are constituted by distinctly human actions as shaped by evolution, history and civilization.

We develop here a different line on cultural economics and its relation to economics of growth and innovation than is usually pursued in the mainstream literature. Currently, there are two distinct meanings of the economics of culture. The first is the application of microeconomic analysis to the problem of efficient cultural production and consumption. This is cultural economics. The second is how culture, as socially learned preferences and knowledge, affects economic behaviour and outcomes. This is the cultural foundations of economics.

Cultural economics is a branch of applied microeconomics concerned with the efficiency of the production and consumption of cultural goods and services. It is built around the supposition of widespread market failure (Throsby 1994) and the welfare maximizing potential of government intervention in cultural markets. There is little connection to economics of growth and innovation, although that does occur in the 'creative industries' end of this field of study (Potts 2011). However, the economics of arts and culture shares the same analytic set up as the economics of science and new knowledge, in being the analysis of a public good beset by market failure. The diagnosis of a positive externality, and the policy solutions, tend to be similar.

The other line through which culture enters economics is through norms, habits and routines as endogenous preferences and cultural capital, as the cultural foundations of economics. Culture is thus a theory of individual preferences acquired through social learning (Boyd and Richerson 2005, Mesoudi 2011). This explains the existence of homogeneity in populations of interacting individuals, and quasi-stable group preferences (Bowles 1998). Cooperative behaviours are more likely under these circumstances (Nowak 2006, Bruni et al 2014). These culturally directed social learning models also underpin the formation of social capital (Burt 2000) and cultural capital (Jones 2006).

A fruitful sociological line of inquiry has been to examine the relation between the cultural traits of a group and innovative performance. Shane (1993) found that cultural values of individualism, power distance, and uncertainty 
acceptance correlated positively with innovative performance. A meta study by Taylor and Wilson (2012) confirmed Shane's original findings, but also that certain types of cultural group characteristics associated with collectivism (such as patriotism) were correlated with innovative performance group, while other types (familism and localism) were not. The implication was to point to ways in which manipulation of culture could affect the rate of innovation and thus economic growth and development, which is to say to bring cultural policy within the ambit of innovation policy. However, we want to set out an alternative line of inquiry into the relation between culture and innovation that is based not on culture as a subsector of the economy, nor on characteristic forms of preferences and behaviours, but rather on a conception of culture as generative, and of the cultural economy as a communicative rather than institutional source of newness. This approach derives neither from economics nor sociology, but from the further-away fields of cultural studies (Hartley 2009).

\section{CULTURE, MARKETS \& NOVELTY}

Standard models of rational choice in markets do not necessarily require complete information - it can be stochastic, with models of choice under uncertainty; or it can be partitioned, as in models of bounded rationality; or unbalanced, as in models of asymmetric information. But these models do require complete preferences: this is why they can deal with uncertainty, but not with novelty (Potts 2010, Karpik 2010, Hutter 2010). The difference is that with genuine novelty, as a consequence of innovation, the agent does not necessarily have preferences at all prior to some kind of experience with the new good or service. They have to form preferences with which then to make choices. In standard economic models, this occurs as individual learning. But that is a generally inefficient solution as the number of new goods increases. It also makes no use of specialization.

The general form of the solution to the problem of 'choice under novelty' (cf. choice under uncertainty) was outlined by Earl and Potts (2004) with the use of other people's preferences (i.e. a 'market for preferences'). This approach makes use of specialization and distributed social learning. Building on the work of Schelling (1973) and Kirman (1993) this concept was extended in Potts et al. (2008) to define 
entire sectors that routinely produce novelty (specifically the so-called 'creative industries') as instances of 'social network markets'. The point of this new classification was to note that with choice under novelty and the systematic use of other people's choices and preferences as inputs into individual choice, then the complex socio-cultural networks over which this information flows - use of other people's preferences, observing the choices of others (Beck 2007, Bentley et al. 2011) - play at least as significant a coordination role as price signals. Social network markets thus describe a wide range of economic activity in which because of inherent novelty due to abundant innovation, economic choices are largely determined by the choice of others on a social network.

The significance of the existence of social network markets is that they are an emergent socio-cultural adaptation to continual, abundant flows of novelty - which is to say to in a market-capitalist economy driven by widespread innovation. What is particularly interesting here is that the price system is not the primary coordination mechanism (although once preferences stabilize, it reassumes that role). The relative growth of the creative industries, and the normalization of their business models and market strategies into other parts of the economy, can in part be explained by their place at the leading edge of social network markets that have harnessed cultural processes into market coordination institutions.

Building on the work of Boltanski and Thévenot (2006), Stark (2009) and Balaz and Stark (2010), and Potts (2012) develops the concept of a novelty bundling market that extends the concept of a social network market to incorporate three further conditions. Specifically: (1) multiple novelties experienced at once; (2) a context of search where consumers don't necessarily know what they're looking for but will know it when they find it; and (3) an emergent organizational and market form that intermediates between producers and consumers of novelty.

Examples of novelty bundling markets are situations of abundant continual flows of novelty where consumers of presented with multiple curated novelties at once, usually in a highly social or culturally structured environment such as arts and music festivals, eisteddfods, academic and research conferences, fashion and technology magazines, blogs, think tanks, dating and introduction agencies, and branded garment retailers, among other instances. Novelty bundling markets are a culturally structured platform for processing novelties that have been curated by 
expert amateur consumers (and/or producers) turned professional novelty bundlers. Interestingly, multiple novelties are often easier to consume than singular novelties because of comparison. Also, novelty consumption is often facilitated by occurring in a social context because of social network markets to reduce uncertainty about a novelty's worth (information that is unreliably carried in price, Karpik 2010). This explains the importance of reviews - once a further professional specialism coordinated by novelty-bundling platforms such as newspapers but now routinely crowd-sourced - in social network markets. As Stark (2009) explains, the consumer may not know what they're looking for, but they'll recognize it when they find it. Furthermore, novelties will often present in multiple registers of value (Boltanski and Thévenot 2006), making novelty difficult to evaluate individually and in isolation. Novelty bundling markets can solve this problem by bundling novelties and organizing a socio-cultural context of comparative choice through the institutions and affordances of the market itself, such as the design or layout.

Social network markets and novelty bundling markets are thus two ways of conceptualizing how when the consumer problem shifts from scarcity to abundance the social economy is part of the solution through the evolution of more complex cultural technologies for processing those increased flows of information.

\section{THE INNOVATION COMMONS}

The social economy is an important part of the innovation economy, yet this is poorly recognized in innovation theory, and even less so in innovation policy. The exceptions are work on user-communities and innovation (e.g. von Hippel 1986) and work on knowledge commons (Frischmann et al 2014), both of which Potts (2014) generalizes toward the idea of an innovation commons. The reason for this theoretical oversight and policy vacuum traces to the underlying analytic formulation of the socalled 'innovation problem'.

As initially formulated by Nelson (1959) and Arrow (1962a), the innovation problem was specified in the language of welfare economics and microeconomic theory as market failure in the production of a public good (new information). The causes of the market failure are the fixed costs of discovery, appropriation (copying), and marginal cost pricing under perfect competition. Something has to give, and the 
various departures and interventions to create rents to compensate for the fixed costs form the various stations of innovation policy. Intellectual property enables a monopoly rent to compensate for the fixed costs. $R \& D$ tax credits offset fixed costs. Targeted industry or technology policy creates artificial effective demand. Higher education subsidizes inputs into innovation investment. Public science nationalizes those fixed costs. In all cases, these involve a government solution, although sometimes, as with intellectual property or tax credits, this works through a market mechanism.

These government solutions are designed to correct market failure. But there are also governance solutions that emerge when the innovation problem is translated from a market failure problem (fixed costs, free copying, and marginal cost pricing under perfect competition) to a collective action problem (free-riding in the creation of a public good). By conceptualizing the innovation problem directly as a (local) public good problem, this opens the way to see commons-type solutions as a third possibility besides market and government solution, with their standard solutions of private property enclosure or public regulation (Ostrom 1990). Community governance mechanisms can work for a knowledge or innovation commons, just as for a natural resource commons, by creating systems of rules that enable a community to cooperatively create new information and technologies. But unlike a natural resource commons, where the problem is avoiding over-exploitation (Hardin's 'tragedy of the commons'), a knowledge or innovation commons has the inverse problem of avoiding under-contribution, such that the new technology or innovation is never developed because the community cannot arrive at mechanisms to enable contributions to occur and information and resources to be pooled and shared.

There has been much recent work on so-called 'peer production' (Benkler 2007), the most well-known examples of which are open-source software and collaborative projects such as Wikipedia. Several hypotheses explain the particular timing of the rise of peer production, from falling transactions costs of organization (Shirky 2008), growing surplus of wealth, time and technology available for reuse (Shirky 2010), to rise in education and ethics of sharing (Leadbeater 2008). However, peer production is also a natural form of human production (the market and hierarchic forms are the long-run aberrations). This line of argument increasingly rests in the 
evolved nature of the humans as a highly cooperative species (Nowak 2006, 2011; Bowles and Gintis 2009; Bruni et al 2014).

An innovation commons emerges when we extend peer production, and the commons governance mechanisms that sustain those institutions of cooperation and protect against free-riding, to the production of new information and knowledge, to discovery and innovation. Innovation commons differ from other peer production commons by the extent of fundamental uncertainty. Most successful commons, and especially in natural resource situations, work because under usually specific circumstances they are simply more efficient ways of organizing production than alternative modes that use markets or hierarchies. Uncertainty does not enter into it. But an innovation commons is marked, by definition, with fundamental uncertainty about the value of what will be produced, the specific way it will be done (i.e. the technology), and therefore what the most valuable assets and contributions will be. The value of an innovation commons comes precisely in furnishing an institutional governance mechanism to facilitate the pooling and sharing of information under conditions of extreme uncertainty. This is valuable, and it is a product of the social economy.

In Pottss (2014) model of innovation commons the resources necessary for innovation include the standard suite of material things, technologies, and contributions of time and money, but also information about the nature of the entrepreneurial opportunity. This is the information about costs, risks, market demand and likely sites of production, all of the information necessary to invest in starting a profitable firm. So there are two resources required for innovation - things and information - and while the things can be provided, incentivised or protected through property rights or government provision, the information is much harder to produce through those institutions. But a commons is a near ideal form for such. An innovation commons, such as a hackerspace (Kostakis et al. 2014), is actually two commons: a commons of shared resources of tools and things, and also an information commons of pooled and shared information that would otherwise be distributed and costly to assemble into useful information.

An innovation commons is a socio-cultural proto-organizational form to produce coherent information for entrepreneurial venturing, and thus for the start of a evolutionary technological trajectory, the result of which becomes an ecology of firms 
and markets, as an industry. Note that the agents in an innovation commons are not yet entrepreneurs - that is a subsequent phase - but more typically they are collaborative enthusiasts. They are connected and coordinated through socio-cultural not contractual mechanisms.

The innovation commons model suggests the existence of a previously unrecognized 'zero-th phase' of what is normally a three-phase industry life cycle trajectory, in which phase 1 is entrepreneurial formation of early firms, phase 2 is the Schumpeterian build out (otherwise known as creative-destruction), and phase 3 is industry maturity. Phases 1-3 unfold in a market-government space, with social economy concern usually concentrated about the latter part of phase 2 and the penultimate state of phase 3 . But the innovation commons approach suggests that the social economy assembles the necessary conditions for the growth of knowledge far earlier, in a phase before entrepreneurial contracting is even possible by furnishing cultural human conditions to pool and gather new ideas and for the sloughing of uncertainty. McCloskey's (2015) humanomics approach to the study of 'how betterment became ethical' and how social equality drove the growth of knowledge in the early Bourgeois era makes a not dissimilar claim.

\section{DEMIC CONCENTRATION \& INNOVATION}

The above two models are examples of cultural production of innovation. A third and in many ways consequent class of model - called the theory of 'demic concentration' (Hartley and Potts 2014) - makes this a two-step process in which culture does not produce innovation directly, but rather culture produces groups and groups produce knowledge. In this approach, which combines sociology, socio-economics and cultural studies, groups, with knowledge, compete, giving rise to conflict and also alliances that inevitably redraw the boundaries of those groups, thus redrawing the map of ideas that are meaningful within those groups, and thus that which can be individually learned (worked out independently) or socially learned (copied from the cultural repertoire). This cultural annealing process of group dynamics and the evolution of meaningfulness is a source of novelty, newness, and innovation arising from the social economy. 
The theory of demic concentration is based on modern evolutionary theory in which culture is not viewed as an end in itself, or some crowning human flourish, but as a human evolutionary adaptation. The selective value of culture is that it makes groups; and the selective value of groups is that they make knowledge. Culture acts as the 'survival vehicle' (Pagel 2012: 12-13) for knowledge and technologies, and thus the group, hence solving the problem of inheritance of knowledge by securing it at group-historical rather than individual-behavioural level. Culture is not something that groups do; rather groups are something that culture does. In this view H. Sapiens is a language-using, high-trusting, instinctively cooperative pro-social groupish animal (Dopfer 2005; Bowles and Gintis, 2011; Nowak 2011; Stoelhorst and Richerson, 2013; Wilson et al, 2013). Culture is the mechanism we use to form groups, and these groups (in-groups, that distinguish from out-groups) are the sites of cooperation and knowledge making.

Hartley and Potts (2014) call a culture-made group a deme. In biology, a deme refers to an inter-breeding group that shares genes, and in political science a demos is an inter-voting group that shares citizenship. Evolved human nature is both altruistic (pro-social) and parochial (adversarially groupish) (Bowles and Gintis 2011; Pagel 2012). We cooperate within a social group, but can be vicious to outgroups (Tajfel 1970). In other words, our groupishness is also groupish (Gintis 2012): we make ingroups and outgroups, and the identifying characteristic of a deme is that it distinguishes itself from other demes, via inclusion/exclusion institutions from language and story to law and religion. Cultural dynamics work along the boundaries of groups, at the level of communicating groups and systems, not individuals (Luhmann 1991). Ideas and knowledge are 'culturally situated' in the sense that we acquire ideas preferentially from our deme: from within our language, our social references, our (extended) family or trusted non-kin 'honorary relatives' (Pagel 2012): from within our 'we-group' and against 'they groups'. (As signaled earlier, this is also a solid finding from science and technology scholars (see Williams and Edge 1996).) This groupishness explains what we call 'universal-adversarialism': within a trusted 'we'-group all knowledge is knowable and universally accessible; but it is opposed to the untrusted knowledge of 'they'-groups.

Culture is an adaptation that enables humans to make groups. A deme, conceived as a culturally-made group, is an autopoietic communicative system of 
externalized knowledge (Luhmann 1986) - externalized in technology (Arthur 2009) and other exosomatic forms as well as in the 'linked brains' (crowd-source) of a group. Demes - both territorial and 'mentifacts' (Huxley 1955); and growing in number over historical time, especially demes-per-person per new communications technology (speech, writing, print, electronics, internet)

In cultural science, innovation is a cultural process of ideas being integrated into the 'we'-group as its boundaries are redrawn to include ideas previously or otherwise part of a 'they-group'. That is, an idea can be acquired through individual or social learning only if it already exists within an individual's deme, and is therefore meaningful. Newness and innovation occur by an evolutionary semiotic process of group-dynamics we call 'demic concentration'. Demic concentration is the formation of such a bounded group; $c f$. demic diffusion (Cavelli-Sforza 2000) where the knowledge moves across groups through individual migration. With demic diffusion, knowledge flows out (e.g. farming practices across Neolithic Eurasia, carried by individuals, not by mere copying). With demic concentration, conversely, knowledge flows in: but because of low-trust settings for 'they'-group originated knowledge, it cannot simply be copied but must be translated into 'we'-group terms (Lotman 1990). With demic concentration, the boundaries of a 'knowledge-group' change: this boundary change is innovation.

There are multiple mechanisms by which culture makes demes. The oldest is through stories (Booker 2004, Boyd 2009). The economics of stories has been developed in the context of the rhetoric of economics (McCloskey 1985, McCloskey and Klamer 1995). McCloskey (2010) argues that the moral virtues of the bourgeois story explain the rise of industrial capitalism in the West. Stories bind individuals to groups, but also to the purposes of those groups, which can then be exploited by leaders in the service of, for example, nation-building (war journalism about national character) or employee loyalty and effort (stories of corporate culture, e.g. Harari (2014) on Peugeot). Stories create meaningful selves and citizens and therefore demic communities, as can be seen in journalism (Hartley 1992), but so too do children and especially youth (child-groups beyond kin) as they remake culture anew (Konner 2010).

Culture is usually viewed as a repository of past knowledge, artifacts and ways of being that constitute collective identity and heritage, sometimes called 'cultural 
capital' (Throsby 1999). But the purpose of culture is not (only) to carry the past, but (also) to invent the future: the semiotic or cultural system - the 'semiosphere' (Lotman 1990, 2009) - must be stable enough to use, flexible enough to adapt and generative along its interconnecting edges. Culture creates demes and demes carry and coordinate knowledge as interacting semiospheres. The growth of knowledge therefore requires changes in the boundaries of those semiospheres, including in the number of them available for habitation by any one individual.

Such boundary changes will not necessarily appear as creative innovation. More likely, they will look like systemic clash and conflict (Vedres and Stark 2010) what Hartley and Potts (2014: ch 4) call malviosine ('bad neighbor'). Bad neighbors have different knowledge. That is why they are different groups. Equivalently, good neighbors have similar or relatable knowledge. That is how cooperation is possible; knowledge among members is interoperable. But different knowledge ('outknowledge' as it were) is also valuable as a source of innovation and spur to adaptation for ingroups. Different knowledge in external groups is simply not available in a way that can be easily accessed or used. It cannot be socially learned. Indeed, it tends to be repelled and may be strongly protected by the outgroup. The clash of demic systems, which concentrates in world cities for instance, is in this way productive of newness, meaningfulness and the reinvention of culture.

Culture plainly carries past knowledge, identity and meaning, and a societal form of capital and wealth. This basic model of culture that runs through anthropology, sociology and cultural economics forms the standard approach to cultural policy as the preservation of a stock of cultural capital and wealth. But culture is also a mechanism to produce newness and grow knowledge. Even more, culture is a mechanism to produce newness from sources that cannot be identified in advance, but which may arise at any point throughout and among social and semiotic systems. Culture is thus not only a mechanism to maintain and reproduce past knowledge (culturally embodied, or socially learned), but also a mechanism for the production of new knowledge.

This 'cultural science' approach derives from a theme arising out of cultural studies - the study of ordinary culture in the Raymond Williams (1958) sense - of culture as productive, and specifically as productive of novelty. Culture makes groups, groups make knowledge, and new ideas (contributions to knowledge) occur as 
the tensioned and conflicted boundary of a group changes. Newness and novelty are not the production of an idea, using factor inputs (the production function for ideas), but the reformation of a group boundary such that an idea becomes meaningful. This is the evolutionary model of cultural dynamics through the mechanisms of demic concentration.

\section{CONCLUSION}

On the face of it these three domains we have examined - how consumers deal with novelty (in section 3); the common pooling of information for invention and market discovery (in section 4); and the role of culture in group formation, and therefore knowledge making (in section 5), might seem disparate. But what ties these domains together is that they are all instances of social cooperation in the face of uncertainty to produce and process new ideas. What is interesting about this approach is that it subverts the 'individual creative genius' model of invention and rests firmly on a model of the coordination of distributed information, or the social use of information to create and navigate novelty in order to realize value. These are three distinct but interlocking parts of the process by which invention and innovation is a social process.

For the past half-century and more, social economics has sought to elucidate and investigate the relationship between the economy and social values. It has developed theories of the behaviors and interactions of economic agents through concepts of social capital and social markets, and examined the social impact of economic change. It has been suggested that the overriding conception of the relation of the social economy to government and market maps to the Freudian scheme of a critical, moralizing social economy super-ego to the rational ego of government market-failure correctives and the $i d$ of the market's basic instinctual drives. This super-ego conception of the social economy is descriptive of the modern research program of social economics. But an unintended consequence is that this same conception tends to overlook how some of the id-like basic social drives and instincts, particularly in relation to knowledge-sharing and collective ways of dealing with uncertainty, and the way in which atavistic and deeply human socio-cultural forces affect how novelty and knowledge is produced within economic systems. There is an opportunity here, we suggest, to advance a positive line of analysis of the social 
economics of innovation by integrating these socio-cultural mechanisms and processes.

We have sought to make two contributions. First, to locate social economics within the literature on the economics of growth and innovation, finding that the extant explanations by and large ignore the role of the social economy as an explanatory mechanism. This is traced to the way new knowledge is represented as either a product of discovery or learning. We show how the economics of culture is boxed within these options, systematically excluding a further possibility - namely as generative of innovation.

As such, the social economy produces rather than simply governs innovation. This, then, is the second contribution, in setting out three new suites of models to explain how innovative activity is shaped by social processes. These are models of socially coordinated markets; culturally incentivized innovation commons; and a model of cultural production of newness and innovation. These three models represent different aspects of the way in which the social economy is generative of newness and of the production of novelty and innovation. We suggest they furnish a candidate frontier for research into how the social economy produces innovation.

\section{REFERENCES}

Aghion P, Howitt, P. (1992) 'A model of economic growth through creative destruction' Econometrica, 60(2): 323-52.

Arrow, K. (1962a) 'Economic welfare and the allocation of resources for invention' R Nelson (ed) The Rate and Direction of Inventive Activity. Princeton University Press: Princeton. pp. 609-26.

Arrow, K. (1962b) 'The economic implications of learning by doing' Review of Economic Studies, 29(3): 155-73.

Arthur, W.B. (2009) The Nature of Technology: What It Is and How It Evolves. New York: Free Press.

Balazs, V., Stark, D. (2010) 'Structural folds: Generative disruption in overlapping groups' American Journal of Sociology, 115(4), 1150-90. 
Beck, J. (2007) 'The sale effect of word of mouth: A model for creative goods and estimation for novels' Journal of Cultural Economics, 31(1): 5-23.

Benkler, Y. (2006) The Wealth of Networks. Yale University Press: New Haven.

Bentley, A., Earls, M., O’Brien, M. (2011) I'll have what she's having: Mapping social behavior. MIT Press: Cambridge, MA.

Bijker, W, Hughes, T., Pinch, T, eds. (1987) The Social Construction of Technological Systems. MIT Press: Cambridge MA/London.

Boltanski, L., Thévenot, L. (2006) On justification: The economies of worth. Princeton: Princeton University Press.

Booker, C. (2004) The Seven Basic Plots: Why we tell stories. Bloomsbury Academic: London.

Boulding, K. (1956) The Image: Knowledge in life and society. University of Michigan Press: Ann Arbor.

Boulding, K. (1964) The Meaning of the 20th Century: The great transition. New York: Harper \& Row.

Boulding, K. (1978) Ecodynamics: A new theory of societal evolution. Sage: Beverly Hills.

Bowles, S. (1998) Endogenous preferences: the cultural consequence of markets and other economic institutions' Journal of Economic Literature, 36: 75-111

Bowles, S., Gintis, H. (2011) A Cooperative Species: Human reciprocity and its evolution. Princeton: Princeton University Press.

Boyd, B. (2009) On the Origin of Stories: Evolution, cognition, and fiction. Cambridge, MA: Harvard University Press.

Boyd, R., Richerson, P. (2005) The Origin and Evolution of Cultures. Oxford: Oxford University Press.

Bruni, L., Panebianco, F., Smerrilli, A. (2014) 'Beyond carrots and sticks: How cooperation and its rewards evolve together' Review of Social Economy, 72(1): 55-82.

Burt, R. (2000) 'The network structure of social capital' Research in Organizational Behavior, 22: 345-63.

Cavalli-Sforza, L. (2000) Genes, Peoples, and Languages, New York: North Point Press. 
Dopfer, K. (2004) 'The economic agent as rule maker and rule user: Homo Sapiens Oeconomicus' Journal of Evolutionary Economics, 14: 177-95.

Dopfer, K., Potts, J. (2008) The General Theory of Economic Evolution. Routledge.

Dosi, G. (1988) 'Sources, procedures and microeconomics effects of innovation' Journal of Economic Literature, 26: 1120-71.

Dosi, G., Marengo, L., Fagioli, G. (2005) 'Learning in evolutionary environments' in K Dopfer (ed) Evolutionary Foundations of Economics. Cambridge University Press: Cambridge.

Earl, P.E., Potts, J. (2004) 'The market for preferences' Cambridge Journal of Economics, 28: 619-33.

Elam, M. (1993) 'Markets, morals and powers of innovation', Economy and Society, 22(1): $1-41$

Emami, Z. (2012) 'Social economics and evolutionary learning' Review of Social Economy, 70(4): 401-20.

Etzioni A (1988) The Moral Dimension: Toward a new economics. Free Press: New York.

Feyerabend, P. (1975) Against Method. Verso Books: New York.

Freeman C (1995) 'The national system of innovation in economic perspective' Cambridge Journal of Economics, 19(1): 5-24.

Frischmann B, Madison M, Strandburg K (eds) (2014) Governing Knowledge Commons. Oxford University Press: New York.

Gintis, H. (2012) Human Evolution: A behavioral synthesis. New Mexico: Santa Fe Institute.

Greif, A. (2006) Institutions and the Path to the Modern Economy: Lessons from medieval trade. Cambridge University Press: Cambridge.

Hall, P., Soskice, D. (2001) Varieties of Capitalism: The institutional foundations of comparative advantage. Oxford University Press: Oxford.

Harari, Y.N. (2014) Sapiens: A brief history of humankind. Harvill Secker: London.

Hartley, J. (1992) The Politics of Pictures: The creation of the public in the era of popular media. London: Routledge.

Hartley, J. (2009) The Uses of Digital Literacy. Brisbane: University of Queensland Press. 
Hartley, J., Potts, J. (2014) Cultural Science: A natural history of stories, demes, knowledge and innovation. Bloomsbury: London.

Hutter, M. (2010) 'Familiar surprises: Creating value in the creative industries'. In P. Aspers \& J. Beckert (eds) The Worth of Goods. Cambridge: Cambridge University Press.

Huxley, J. (1955) 'Guest Editorial: Evolution, Cultural and Biological'. Yearbook of Anthropology, 2-5.

Jones, E. (2006) Cultures Merging. Princeton University Press: Princeton.

Karpik L (2010) Valuing the Unique: The economics of singularities. Princeton University Press: Princeton.

Kirman A. (1993) 'Ants, rationality and recruitment', Quarterly Journal of Economics, 108: 137-56.

Konner, M. (2010) The Evolution of Childhood. Cambridge MA: Harvard University Press.

Kostakis, V., Niaros, V., Giotitsas, C. (2014) 'Production and governance in hackerspaces: A manifestation of Commons-based peer production in the physical realm?' International Journal of Cultural Studies (OnlineFirst).

Leadbeater, C. (2008) We Think: Mass Innovation, Not Mass Production. London: Profile Books.

Loasby, B. (1999) Knowledge, Institutions, and Evolution in Economics. Routledge: London.

Lotman, Y. (1990), Universe of the Mind: A semiotic theory of culture. Bloomington: University of Indiana Press.

Lotman, Y. [J.] (2009) Culture and Explosion. Berlin: Mouton De Gruyter.

Luhmann, N. (1986) 'The autopoeisis of social systems'. In F. Geyer \& J. van der Zouwen (eds) Sociocybernetic Paradoxes. London: Sage Publications, pp. 172-92.

Luhmann, N. (1991) 'What is communication?' Communication Theory, 10: 251-9. Lundvall BÅ (ed) (1992) National Systems of Innovation. Pinter: London. MacKenzie, D. Wajcman, J. (eds), (1985) Social Shaping of Technology: How the refrigerator got its hum. Open University Press: Milton Keynes.

Martin S, Scott J (2000) 'The nature of innovation market failure and the design of public support for private innovation' Research Policy, 29(4-5): 437-47. 
McCloskey D (2015) Bourgeois Equality: How betterment became virtuous, 16001848, and then suspect ( 2015). University of Chicago Press: Chicago.

McCloskey, D. (1985) The Rhetoric of Economics. University of Wisconsin Press: Madison.

McCloskey, D. (2010) Bourgeois Dignity: Why economics can't explain the modern world. University of Chicago Press: Chicago.

McCloskey, D., Klamer, A. (1995) 'One quarter of GDP is persuasion’ American Economic Review, 85: 191-5.

Mesoudi, A. (2011) Cultural Evolution. University of Chicago Press: Chicago.

Mulgan, G. (2013) The Locust and the Bee. Princeton University Press: Princeton.

Nelson R (1959) 'The simple economics of basic scientific research' Journal of Political Economy, 67(3): 297-306.

Nelson R, Winter S (1982) An Evolutionary Theory of Economic Change. Harvard University Press: Cambridge, MA.

Nelson, R. (1993) National Innovation Systems: A comparative study. Oxford University Press: Oxford.

Nelson, R. (2011) 'The Moon and the Ghetto revisited' Science and Public Policy, 38(9): 681-90.

North, D. (2005) Understanding the Process of Economic Change. Princeton University Press: Princeton.

Nowak, M. (2006) 'Five rules for the evolution of cooperation' Science, 314(5805): $1560-3$.

Nowak, M. (2011) Supercooperators. Free Press: New York.

Ostrom, E. (1990) Governing the Commons. Cambridge University Press: Cambridge.

Pagel, M. (2012) Wired for Culture: The Natural History of Human Cooperation. London: Allen Lane.

Popper, K. (1972) Objective Knowledge: An evolutionary approach. Oxford: Clarendon Press.

Potts, J. (2010) 'Can behavioural biases in choice under novelty explain innovation failures?' Prometheus, 28(2): 133-48.

Potts, J. (2011) Creative Industries and Economic Evolution. Cheltenham: Edward Elgar. 
Potts, J. (2012) 'Novelty bundling markets' Advances in Austrian Economics, 16: 291-312.

Potts, J. (2014) 'Theory of innovation commons’ Unpublished Working Paper.

Potts, J., Cunningham, S., Hartley, J., Ormerod, P. (2008) 'Social network markets: A new definition of creative industries' Journal of Cultural Economics, 32(3): $166-185$.

Rodrik, D. (2007) One Economics, Many Recipes. Princeton University Press: Princeton.

Romer P (1986) 'Increasing returns and long run growth' Journal of Political Economy 94: 1002-37.

Sarewitz, D., Nelson, R. (2008) 'Progress in know-how: its origins and limits' Innovations. 101-17.

Schelling, T. (1973) 'Hockey helmets, concealed weapons, and daylight saving: A study of binary choices with externalities' Journal of Conflict Resolution, 17(3): 381-428.

Schumpeter J (1934) Business Cycles. McGraw Hill: New York.

Shane, S. (1993) 'Cultural influences on national rates of innovation' Journal of Business Venturing, 8: 59-73.

Sharif, N. (2006) 'Emergence and development of the national innovation systems approach' Research Policy, 35(5): 745-66.

Shirky, C. (2008) Here Comes Everybody. Allen Lane, New York.

Shirky, C. (2010) Cognitive Surplus. Penguin Press: New York.

Solow, R (1956) ‘A contribution to the theory of economic growth' Quarterly Journal of Economics, 70(1): 65-94.

Stark, D. (2009) The Sense of Dissonance: Accounts of worth in economic life. Princeton: Princeton University Press.

Stigler, G. (1961) 'The economics of information' Journal of Political Economy, 69(3): 213-25.

Stoelhorst, J., Richerson, P. (2013) 'A naturalistic theory of economic organization' Journal of Economic Behavior and Organization, 90: S45-56.

Tajfel, H. (1970) 'Experiments in intergroup discrimination'. Scientific American, 223: 96-102. 
Taylor M, Wilson S (2012) 'Does culture still matter? The effects of individualism on national innovation rates' Journal of Business Venturing, 27, 234-47.

Throsby, D. (1994) 'The production and consumption of the arts' Journal of Economic Literature, 32: 1-29.

Throsby, D. (1999) 'Cultural capital' Journal of Cultural Economics, 23: 3-12.

Vedres, B., D. Stark (2010) 'Structural folds: Generative disruption in overlapping groups' American Journal of Sociology, 115(4): 1150-90.

Von Hippel, E. (1986) 'Lead users: A source of novel product concepts' Management Science, 32(7): 791-805.

Williams, R. (1958) ‘Culture is ordinary’ Reprinted in B. Highmore, ed. (2002) The Everyday Life Reader. London: Routledge, pp. 91-100.

Williams, R., Edge, D. (1996) 'The social shaping of technology' Research Policy, 25: 865-99.

Wilson, D.S., Ostrom, E., Cox, M. (2013) 'Generalizing the core design principles for the efficacy of groups' Journal of Economic Behavior and Organization, 90: S21-32.

Ziman, J. (2000) 'Evolutionary models of technological change' in J. Ziman (ed) Technological Innovation as an Evolutionary Process. Cambridge University Press: Cambridge. pp. 3-12. 